\title{
SUBSTITUSI FILLER PADA CAMPURAN ASPAL DENGAN FLY ASH DAN SERBUK BATU BATA
}

\author{
Mohammad Zainudin Abdillah ${ }^{1}$, Dwi Kartikasari ${ }^{2}$ \\ ${ }^{1]}$ Program Studi Teknik Sipil Fakultas Teknik Universitas Islam Lamongan \\ ${ }^{2}$ Dosen Progam Studi Teknik Sipil Fakultas Teknik Universitas Islam Lamongan \\ email:abdillahzainudin57@gmail.com,dkartika27@gmail.com
}

\begin{abstract}
Asphalt concrete wearing course as a wear layer in highway pavement layer, Is the top layer in flexible pavement. In this research will be discussed on the use of Portland cement filler as a reference to compare filler replacement with fly ash and powdered brick with 100\% fly ash, 100\% powdered brick and 50\% fly ash: 50\% powder brick. The first step after the aggregate testing, the asphalt and filler material to be used, followed by the manufacture of the specimen with the specified asphalt content. After obtaining the optimum asphalt content for each different filler variation, a Marshall test was performed to obtain flow stability and density values. In this research we get the optimum asphalt content value of 5,5\% for each specimen. The result of this research mixed with good quality using 100\% Portland cement filler stability value of $112.19 \mathrm{~kg}$ and the lowest using filler $100 \%$ fly ash but the result still meet the specifications of clan. While the MQ value with 100\% filler of brick powder under specification of Bina Marga is 213. So it can be concluded that a good filler for asphalt concrete wearing course mixture is with Portland cement.
\end{abstract}

Keywords: Filler, Fly Ash, Brick Powder, Asphalt AC-WC

\section{PENDAHULUAN}

Campuran aspal panas atau yang sering disebut hotmix merupakan jenis campuran yang dibuat, dihamparkan dan dipadatkan dalam kondisi panas. Menurut Spesifikasi Kementrian Pekerjaan Umum Direktorat Jendral Bina Marga.salah satu jenis hotmix yang umumnya dipakai di Indonesia adalah Asphalt Concrete ( $A C)$. AC atau aspal beton itu sendiri terbentuk dari agregat kasar, agregat halus, aspal sebagai bahan perekat dan filler sebagai bahan pengisi.

Persyaratan filler menurut Kementrian Pekerjaan Umum Direktorat Jendral Bina Marga tahun 2010 harus dalam kondisi kering, bebas dari gumpalan-gumpalan dan lolos ayakan No 200. Berdasarkan ketentuan tersebut, dalam aplikasi di lapangan, filler sering menggunakan semen karena mengandung kapur tohor $60-65 \%$, silica 20$24 \%$ dan alumina sekitar $4-8 \%$. Kandungan bahan tersebut mempengaruhi stabilitas dan viskositas campuran aspal. Namun hal tersebut tidak menutup kemungkinan adanya penggunaan filler lain selama masih memenuhi ketentuan yang disyaratkan. Jurnal sipil vol 4 Fauzi (2012) menyebutkan dalam sebuah blog bahwa batu bata memiliki sebagian besar silika sebesar $47 \%$ dan alumina sebesar $47 \%$. Senyawa kimia yang terkandung dalam batu bata juga memiliki kemiripan dengan senyawa kimia dalam kandungan serta komposisi kimia dari fly ash batu bara sebagian besar tersusun dari unsur-unsur $\mathrm{Si}, \mathrm{Al}, \mathrm{Fe}, \mathrm{Ca}$, serta $\mathrm{Mg}, \mathrm{S}, \mathrm{Na}$ dan unsur kimia yang lain. Berdasarkan penelitian yang dilakukan oleh Moultonser. Jurnal sipil vol 2 Ambarwati dan Arifin (2009) batu bata dapat dijadikan penganti semen.Oleh karena itu, pada penelitian kali ini akan menggunakan fly ash batu bara sebagai pengganti filler semen Portland yang akan dikombinasikan dengan batu bata. Penelitian ini merupakan eksperimen dan akan dilihat pengaruhnya dari Penggantian Filler Fly Ash 
Batu Bara dan Serbuk Batu Bata Pada Asphalt Concrete - Wearing Course (AC-WC). Tujuan penelitian ini adalah untuk mengetahui pengaruh penggunaan filler dengan fly ash batu bara dan serbuk batu bata pada campuran Asphalt Concrete - wearing Course (AC-WC) yang terdiri dari stabilitas, flow, dan Marshall Quotient dan untuk mengetahui nilai presentase optimum diantara filler fly ash serbuk batu bata dan fly ash dibanding serbuk batu bata dengan presentase 100:0, 50:50 dan $0: 100$.

\section{METODE PENELITIAN}

Pelaksanaan penelitian seperti pembuatan benda uji, perawatan dan pengujian benda uji dilakukan di Laboratorium Program Studi Teknik Sipil Fakultas Teknik Universitas islam lamongan.Penelitian yang akan diuji pada campuran Asphalt Concret Wearing Course $(A C-W C)$ adalah Marshall test dengan variasi penggantian sebagian filler 100:0, 50:50, 0:100 dimana bahan utama filler berupa semen portland dan filler pengganti berupa kombinasi dari fly ash dan serbuk batu bata.Semua bahan yang digunakan pada penelitian ini mengacu pada spesifikasi umum yang dikeluarkan oleh Direktorat Jenderal Bina Marga tahun 2010 Revisi I.

\section{Tahapan Penelitian}

Pelaksanaan penelitian yang dilaksanakan di Laboratorium Program Studi Teknik Sipil Fakultas Teknik Universitas Islam Lamongan disajikan dalam gambar diagram bagan alir penelitian

\section{Persiapan Bahan}

Bahan yang digunakan dalam penelitian ini meliputi :

\section{Agregat kasar (split)}

Agregat kasar yang digunakan pada penelitian ini yaitu agregat alami yangdipecahkan (split), agregat ini berasal dari PT Cahaya Indah Pratama.

\section{Agregat sedang}

Agregat ini menggunakan agregat alami yang di peroleh dari PT.Cahaya Indah Pratama yaitu berbentuk pipih

3. Agregat halus

Agregat halus yang digunakan pada penelitian ini berupa abu batu yang disaring, agregat halus ini berasal dari PT Cahaya Indah Pratama.

\section{Filler}

Penelitian ini berupa eksperimen dari penggantian filler yang dikombinasikan. Terdapat tiga jenis filler yang dipakai yaitu:

\section{A. SemenPortland}

Semen digunakan sebagai bahan utama filler. Semen yang digunakanIII-2adalah Semen Portland yang sesuai dengan standar SNI. Pengamatan dilakukan secara visual pada kemasan kantong $40 \mathrm{~kg}$, kemasan dalam keadaan tertutup dan tidak terdapat kerusakan pada segel maupun kantung.

B. Serbuk Batu Bata.

- Sumber Bahan

Limbah batu bata diambil dari pecahan batu bata merah

- Tahap Pengolahan :

Limbah/sisa batu bata yang telah diambil dijemur terlebih dahulu untuk menghilangkan kadar air, lama penjemuran \pm setengah hari

Setelah kering, batu bata dihancurkan secara manual dengan batu giling hingga menjadi serbuk lalu disaring dengan saringan nomor

200.

C. Fly ash batu bara

D. Aspal yang digunakan adalah aspal penetrasi $60 / 70$

\section{Persiapan Alat}

Semua peralatan yang dibutuhkan untuk penelitian ini tersedia di Laboratorium Fakultas Teknik Universitas Islam Lamongan

\section{Pemeriksaan Aspal}

Pemeriksaan aspal dilakukan untuk mengetahui karakteristik dari aspal keras. Pemeriksaan aspal ini meliputi :

1. Penetrasi aspal(06-2456-1991)

2. Titik Lembek (SNI 06-2434-1991)

3. Titik Nyala, titik bakar (SNI 06-2433-1991)

\section{Pemeriksaan Agregat}

Pemeriksaan agregat kasar dan halus dilakukan untuk memenuhi standar agregat sesuai dengan spesifikasi yang disyaratkan. Pemeriksaan agregat ini meliputi:

1. Pemeriksaan Gradasi Agregat (SNI 031968-1990)

2. Pemeriksaan Berat Jenis dan Penyerapan Agregat (SNI 03-1968-1990) 
3. Pemeriksaan Berat Jenis dan Penyerapan Agregat Halus (SNI 03-1969-1990)

\section{Pembuatan Benda Uji Marshall test}

Setelah semua pemeriksaan agregat memenuhi spesifikasi, langkah selanjutnya yaitu melakukan rancangan campuran (mix design) untuk mendapatkan komposisi agregat kasar agregat sedang agregat halus filler dan kadar aspal optimum.

Bahan-bahan yang digunakan dalam campuran benda uji yaitu agregat kasar, agregat halus dan filler. Agregat dan filler ditimbang sesuai ukurannya berdasarkan gradasi yang diinginkan. Berat total agregat campuran adalah berat agregat yang dapat menghasilkan satu benda uji padat setinggi $6,35 \mathrm{~cm}$ dengan diameter $10,2 \mathrm{~cm}$. Umumnya berat agregat campuran adalah \pm 1200 gram

\section{Prosedur pembuatan benda uji untuk campuran aspal adalah}

1. Persiapan Benda Uji

Bersihkan bahan-bahan yang akan digunakan untuk campuran benda uji lalu keringkan dalam oven pada suhu $110^{\circ} \mathrm{C}$ selama 24 jam. Setelah itu, pisahkan agregat dan filler kedalam wadah berupa nampan/loyang agar mudah pada saat pengambilan. Bersihkan cetakan benda uji lalu buat alas benda uji sesuai dengan diameter cetakan. Sebelum penuangan, bagian dalam cetakan dilapisi oli agar benda uji tidak melekat dengan cetakan dan mempermudah pengeluaran benda uji dari cetakan.

2. Pembuatan Campuran

Panaskan agregat dan filler yang diperlukan dengan cara disangrai dengan suhu diatas $110^{\circ}$ C. Panaskan juga aspal hingga mencapai suhu diatas $110^{\circ} \mathrm{C}$ lalu timbang kadar aspal yang diperlukan dari komposisi campuran yang telah didapat, setelah itu tuangkan aspal sesuai jumlah yang dibutuhkan ke dalam agregat dan filler. Aduk campuran hingga merata.

3. Pemadatan campuran

Setelah campuran aspal tercampur merata diatas suhu $110^{\circ} \mathrm{C}$, pindahkan kedalam cetakan yang telah dilapisi kertas saring yang bagian dasarnya telah dilapisi kertas dan ditusuk-tusuk pada pinggir cetakan dan bagian tengah cetakan yang telah terisi campuran. Lepaskan leher cetakan, ratakan permukaan campuran dengan sendok semen sehingga menjadi sedikit cembung. Letakan cetakan diatas alat pemadat kemudian ditumbuk sebanyak75 kali. Setelah selesai cetakan dibalik dan dilakukan penumbukan kembali sebanyak 75 kali.

4. Perawatan Benda Uji

Benda uji yang telah dipadatkan lalu dikeluarkan dari cetakan dengan dongkrak hidrolik (extruder) dengan meletakkan pelat pengeluar benda uji pada bagian atas cetakan dan lepaskan pelat dasar cetakan. Keluarkan benda uji dengan hati-hati dan rendam benda uji selama kurang lebih 1 hari.

\section{Diagram alir penelitian}

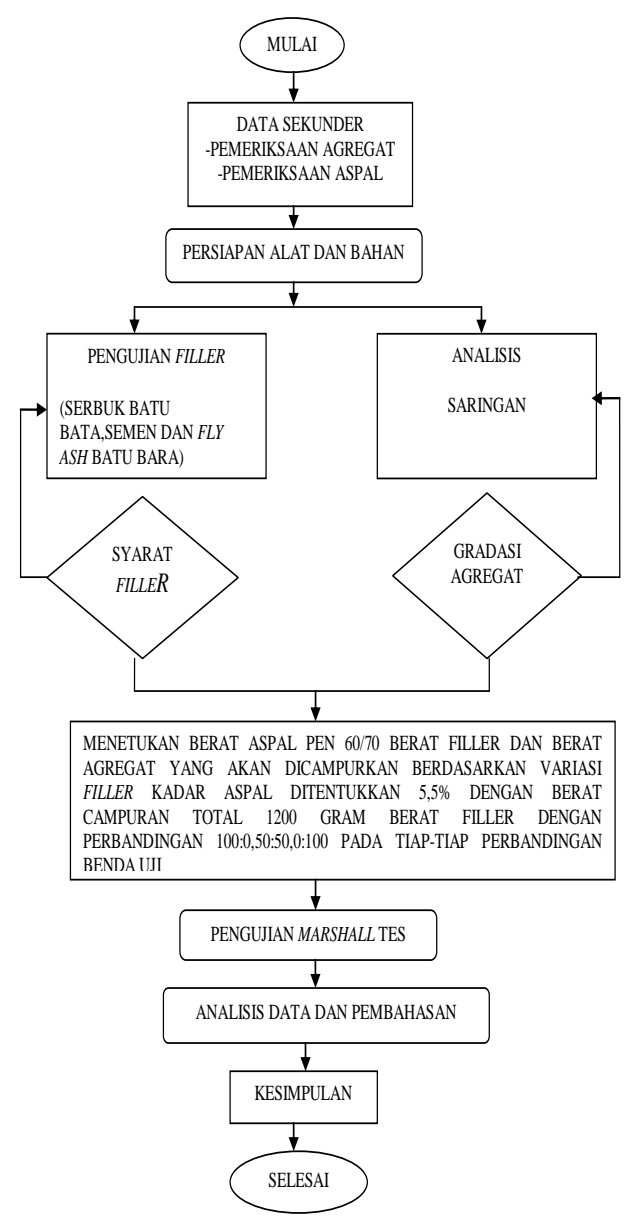

Gambar 1 Bagan alir penelitian

\section{HASIL DAN PEMBAHASAN}

Data yang di peroleh dalam pengujian benda uji yang dilakukan laboratorium Teknik Sipil Universitas Islam Lamongan merupakan 
data awal untuk memperoleh dan mengetahui nilai karakteristik marshall asphalt concrete wearing course $(A C-W C)$ dengan komposisi aspal pen 60/70 dengan pengantian filler fly ash batu bara dan serbuk batu bata. Dan dalam pengujian ini menggunakan kadar aspal 5,5\% dalam hal ini akan dikemukakan hasil pemeriksaan .hasil pengujian benda uji.

\section{Hasil Pemeriksaan Bahan}

Agregat kasar

Hasil pemeriksaan karakteristik agregat kasar pecah ukuran maksimum 3/4" dan 3/8", agregat kasar merupakan kerikil yang ada di laboratorium teknik sipil UNISLA dapat dilihat bahwa agregat kasar ukuran 3/4" dan 3/8" yang telah diuji memiliki kualitas yang sangat baik dan bisa digunakan pada campuran beton aspal dapat dilihat pada tabel 1

Tabel 1 Saringan Agregat

\begin{tabular}{lccc}
\hline Saringan & $\begin{array}{c}\text { Berat } \\
\text { tertahan } \\
\text { (gram) }\end{array}$ & Tertahan & $\begin{array}{c}\text { Lolos } \\
\%\end{array}$ \\
\hline $11 / 2$ & 0 & 0 & 100 \\
\hline 1 & 0 & 0 & 100 \\
\hline $3 / 4$ & 0 & 0 & 100 \\
\hline $1 / 2$ & 2142,5 & 29,96 & 70,04 \\
\hline $3 / 8$ & 5265,5 & 73,62 & 26,38 \\
\hline No.4 & 6895,7 & 96,42 & 3,58 \\
\hline No.8 & 6953,5 & 97,22 & 2,78 \\
\hline No 16 & 7075,8 & 98,93 & 1,07 \\
\hline No 30 & 7102,6 & 99,31 & 0,69 \\
\hline N0 50 & 7114,0 & 99,47 & 0,53 \\
\hline No 100 & 71125,3 & 99,63 & 0,37 \\
\hline No 200 & 7134,6 & 99,76 & 0,24 \\
\hline Sumber: Hasil penelitian & &
\end{tabular}

\section{Hasil Pemeriksaan Berat Jenis Dan Penyerapan Agregat Kasar}

Pemeriksaan berat jenis agregat kasar dengan cara melakukan perhitungan berat jenis bulk, penyerapan dan berat jenis SSD pengujian ini menggunakan sampel dengan berat agregat 4000 gram dengan acuan bina marga (AASHTO-T-85-74) dan PB -0202-76

Tabel 2 Hasil Pengujian Agregat Kasar

\begin{tabular}{lc}
\hline \multicolumn{1}{c}{ Satuan } & Besaran \\
\hline Bk(berat kering oven(gram) & 3526 \\
\hline $\begin{array}{l}\text { Bj(berat kering permukaan } \\
\text { jenuh(gram) }\end{array}$ & 3590,5 \\
\hline Ba(berat benda uji dalam air(gram) & 2215,5
\end{tabular}

\begin{tabular}{|c|c|}
\hline \multirow[t]{2}{*}{ (bulk specific gravity) $=\frac{b k}{b j-b a}$} & $=\frac{3526}{3590,5-2215,5}$ \\
\hline & $=2,56$ \\
\hline \multirow{3}{*}{ (saturated surface gravity) $=\frac{b j}{b j-b a}$} & $-3590,5$ \\
\hline & $3590,5-2215,5$ \\
\hline & $=2,61$ \\
\hline \multirow{3}{*}{ (app.specific gravity) $=\frac{b k}{b k-b a}$} & 3526 \\
\hline & $3526-2215,5$ \\
\hline & $=2,69$ \\
\hline \multirow[t]{2}{*}{ Penyerapan $=\frac{b j-b k}{b k} \times 100 \%$} & $=\frac{3590,5-3526}{3526} \times 100$ \\
\hline & $=1,82 \%$ \\
\hline
\end{tabular}

\section{Sumber : Hasil penelitian}

Dari hasil pengujian pada tabel diatas uji material kasar berat jenis bulk, berat SSD, berat jenis semu serta penyerapan telah sesuai dengan spesifikasi bina marga. Dan SNI 031969-1990 yaitu berat jenis harus min 2,5 dan penyerapan maks $3 \%$.

\section{Pemeriksaan Agregat Halus}

Secara visual semakin kecil ukuran butir agregat maka semakin padat daya serap agreat tersebut hasil pemeriksaan dilakukan di laboratorium teknik sipil UNISLA. Bahan tersebut diperoleh dari abu batu dan menunjukkan agregat halus memenuhi persyaratan sebagai bahan perkerasan hasil pemeriksaan dapat di lihat pada tabel 5 Tes analisa saringan dengan sieve shaker (AASHTO-T 27).

Tabel 3 Tes Analisa Saringan Agregat Halus

\begin{tabular}{lccc}
\hline Saringan & $\begin{array}{c}\text { Berat } \\
\text { tertahan }\end{array}$ & Tertahan & Lolos \% \\
\hline 1 1/2 & 0 & 0 & 100 \\
\hline 1 & 0 & 0 & 100 \\
\hline $3 / 4$ & 0 & 0 & 100 \\
\hline $1 / 2$ & 0 & 0 & 100 \\
\hline $3 / 8$ & 0 & 0 & 100 \\
\hline No.4 & 7,6 & 0,60 & 99,40 \\
\hline No.8 & 200,2 & 15,89 & 84,11 \\
\hline No 16 & 512,4 & 40,68 & 59,32 \\
\hline No 30 & 755,2 & 59,95 & 46,05 \\
\hline N0 50 & 859,2 & 68,24 & 31,76 \\
\hline No 100 & 985,2 & 78,21 & 21,79 \\
\hline No 200 & 1121,5 & 89,03 & 10,00 \\
\hline Sumber : Hasil penelitian & &
\end{tabular}


Dari tabel diatas diketahui uji analisis saringan dengan sieve shaker, agregat halus telah memenuhi spesifikasi bina marga sebagai bahan campur aspal $A C-W C$ dan lolos saringan no.8.

\section{Hasil Pengujian Agregat Halus}

Hasil pengujian agregat halus memenuhi persyaratan sesuai dengan acuan bina marga.

Tabel 4 Hasil Pengujian Agregat Halus

\begin{tabular}{|c|c|}
\hline Satuan & Besaran \\
\hline $\begin{array}{l}\text { Bk (berat sampel oven } \\
\text { kering(gram) })\end{array}$ & 490,3 \\
\hline $\mathrm{B}$ (berat labu+air(gram)) & 629,6 \\
\hline $\begin{array}{l}\text { Bt(berat piknometer+benda uji } \\
\text { SSD+air(gram)) }\end{array}$ & 940,1 \\
\hline (bulk specific gravity) $=\frac{\boldsymbol{b k}}{\boldsymbol{b}+\mathbf{5 0 0}-\boldsymbol{b t}}$ & $\begin{array}{l}= \\
\frac{490,3}{629,6+500-940,1} \\
=2,58\end{array}$ \\
\hline $\begin{array}{l}\text { (saturated surface gravity) }= \\
\mathbf{5 0 0}\end{array}$ & $=$ \\
\hline$\overline{b+500-b t}$ & $\begin{array}{l}629,6+500-940,1 \\
=2,63\end{array}$ \\
\hline$\left(\right.$ app. specific gravity) $=\frac{\boldsymbol{b} \boldsymbol{k}}{\boldsymbol{b}+\boldsymbol{b} \boldsymbol{k}-\boldsymbol{b t}}$ & 490,3 \\
\hline & $\begin{array}{l}629,6+490,3-940,1 \\
=2,72\end{array}$ \\
\hline Penyerapan $=\frac{(500-A) X 100}{A}$ & $\begin{array}{l}= \\
\frac{(500-490,3) X 100}{490,3} \\
=1,97\end{array}$ \\
\hline
\end{tabular}

Sumber : Hasil penelitian

Dari hasil pengujian pada tabel diatas uji material kasar berat jenis bulk, berat SSD, berat jenis semu serta penyerapan telah sesuai dengan spesifikasi bina marga yaitu berat jenis harus min 2,5 dan penyerapan maks $3 \%$

\section{Pengujian Filler}

Pengujian filler bertujuan untuk mengetahui nilai keausan, berat jenis dan waktu ikat filler spesifikasi ini mengacu pada spesifikasi bina marga yaitu lolos saringan no 200 sebanyak $75 \%$ pengujian dilakukan di laboratorium Unisla dengan pengujian tiga filler semen, fly ash dan serbuk batu bata. Hasil pengujian dapat dilihat pada tabel 7
Tabel 5 Hasil Uji Filler

\begin{tabular}{ccccc}
\hline Filler & Keausan & $\begin{array}{c}\text { Lolos } \\
\text { ayakan 200 }\end{array}$ & $\begin{array}{c}\text { Berat } \\
\text { jenis }\end{array}$ & $\begin{array}{c}\text { Waktu } \\
\text { ikat }\end{array}$ \\
\hline Semen & $80 \%$ & $100 \%$ & 3,15 & $60-120$ \\
& & & gram/cc & $\begin{array}{l}\text { menit } \\
\text { gram }\end{array}$
\end{tabular}

\begin{tabular}{|c|c|c|c|c|}
\hline Fly ash & $5-27 \%$ & $90 \%$ & $\begin{array}{l}2,8 \\
\mathrm{gram} / \mathrm{cc}\end{array}$ & $\begin{array}{l}423 \\
\text { menit }\end{array}$ \\
\hline $\begin{array}{l}\text { Serbuk } \\
\text { batu } \\
\text { bata }\end{array}$ & $10-35 \%$ & $80 \%$ & $\begin{array}{l}2,75 \\
\text { gram/cc }\end{array}$ & $\begin{array}{l}345 \\
\text { menit }\end{array}$ \\
\hline
\end{tabular}

Dari tabel diatas filler penganti dapat digunakan sebagai filler pada campuran aspal $A C-W C$. Dari hasil uji menunjukkan semua filler tidak mengandung gumpalan dan di uji pengayakan sesuai SNI 03-6723 -2002 lolos ayakan no. 200 tidak kurang dari $75 \%$.

\section{Pemeriksaan Aspal}

\section{Pemeriksaan Titik Nyala Dan Titik Bakar Aspal}

Pemeriksaan titik nyala dan titik bakar dilaukan di laboratorium teknik sipil Unisla hasil penelitian untuk mengetahui karakteristik aspal.

\begin{tabular}{|c|c|c|c|}
\hline $\begin{array}{c}{ }^{\circ} \mathrm{C} \\
\text { dibawah } \\
\text { titik nyala } \\
\end{array}$ & $\begin{array}{l}\text { Waktu( } \\
\text { menit) }\end{array}$ & ${ }^{\circ} \mathbf{C}$ & $\begin{array}{c}\text { Titik } \\
\text { nyala/titik } \\
\text { bakar }\end{array}$ \\
\hline 96 & 5 & 100 & \multirow{19}{*}{$\begin{array}{l}\text { Titk nyala: } 296^{\circ} \mathrm{C} \\
\text { Titik bakar: } 320^{\circ} \mathrm{C}\end{array}$} \\
\hline 89 & 10 & 142 & \\
\hline 84 & 15 & 160 & \\
\hline 77 & 20 & 170 & \\
\hline 72 & 25 & 180 & \\
\hline 69 & 30 & 182 & \\
\hline 62 & 35 & 190 & \\
\hline 56 & 40 & 160 & \\
\hline 51 & 45 & 180 & \\
\hline 46 & 50 & 200 & \\
\hline 41 & 55 & 210 & \\
\hline 36 & 60 & 226 & \\
\hline 31 & 65 & 244 & \\
\hline 26 & 70 & 258 & \\
\hline 21 & 75 & 270 & \\
\hline 16 & 80 & 282 & \\
\hline 11 & 85 & 296 & \\
\hline 6 & 90 & 308 & \\
\hline 1 & 95 & 320 & \\
\hline
\end{tabular}

Sumber: Hasil penelitian 
Dari tabel diatas nilai titik nyala dan titik bakar pada aspal telah memenuhi dan sesuai dengan pedoman (PA-0303-76) dan SNI 062433-1991 yakni titik nyala $296^{\circ}$ dan titik bakar $320^{\circ}$

\section{Pemeriksaan Penetrasi Aspal}

Pada pengujian material aspal kondisi ruangan juga mempengaruhi hasil pengujian. Hasil pengujian penetrasi pada tabel 7 memenuhi standar spesifikasi SNI 06-24561991.

Tabel 7 Penetrasi Aspal Pen 60/70

\begin{tabular}{lccccc}
\hline Penetrasi & \multicolumn{5}{c}{ Sampel } \\
\cline { 2 - 6 } $\begin{array}{l}\mathbf{2 5}^{\circ} \mathbf{C 1 0 0} \\
\text { gram,5 detik }\end{array}$ & I & II & III & IV & V \\
\hline Pengamatan & 70 & 63 & 73 & 72 & 70 \\
& 65 & 72 & 67 & 73 & 68 \\
& 66 & 67 & 68 & 68 & 70 \\
\hline
\end{tabular}

\begin{tabular}{llllll}
\hline Rata-rata & 67 & 67,3 & 69,3 & 71 & 69,3 \\
\hline
\end{tabular}

Sumber : Hasil penelitian

Dari data diatas dapat diketahui pengujian dengan lima buah benda uji dapat di simpulkan nilai rata-rata pada pengujian penetrasi aspal yaitu sebesar 68,8 jadi sesuai standar aspal yaitu $60 / 70$ pen.

\section{Perencanaan kadar bitumen}

Kadar bitumen yang akan dipaki disesuaikan dengan gradasi campuran yang terjadi diatas

$$
\begin{aligned}
& \mathrm{Pb}=0,035(\% \mathrm{CA})+0,045(\% \mathrm{FA})+ \\
& 0,18(\% \text { filler })+\text { kons } \\
& \mathrm{Pb} \quad=\text { Kadar aspal perkiraan } \\
& \mathrm{CA} \quad=\text { Agregat kasar tertahan saringan no.8 }
\end{aligned}
$$

FA = Agregat halus lolos saringan no 8 dan tertahan saringan no.200

Filler = Agregat halus lolos saringan no. 200

$$
\begin{aligned}
\mathrm{Pb} & =0,035(62,86)+0,045(32,30)+0,18(4,84)+1 \\
\mathrm{~Pb} & =5,52 \% \\
& =5,5 \%
\end{aligned}
$$

$\mathrm{CA}=62,86$

$\mathrm{MA}=32,30$

$\mathrm{FA}=4,86$

$$
100,0
$$

Jadi nilai yang pakai adalah kadar aspal 5,5\%

\section{Komposisi campuran aspal AC-WC}

Sebelum pembuatan benda uji dilakukan pembuatan rancangan campur (mix design) perencanaan campuran meliputi perencanaan gradasi agregat, penentuan aspal dan pengukuran masing-masing fraksi baik agregat, aspal maupun filler. Gradasi yang digunakan adalah standart nasional Indonesia (SNI) pada tabel 8 untuk menghitung kadar aspal yang cocok untuk aspal $A C$-WC sehingga menghasilkan timbangan agregat yang mencapai 1200 gram.

Tabel 8 komposisi material

\begin{tabular}{lll}
\hline No & Material & Komposisi \\
\hline 1 & Agregat kasar & $23 \%$ \\
\hline 2 & Agregat medium & $36 \%$ \\
\hline 3 & Agregat halus & $39 \%$ \\
\hline 4 & Filler & $2 \%$ \\
\hline 5 & Aspal & $5,5 \%$ \\
\hline \multicolumn{2}{l}{ Sumber : Hasil Penelitian } \\
\end{tabular}

$$
\begin{array}{ll}
\text { Material kasar } & =260,8 \text { gram } \\
\text { Material sedang } & =408,2 \text { gram } \\
\text { Material halus } & =442,3 \text { gram } \\
\text { Filler } & =22,7 \text { gram } \\
\text { Aspal } & =66 \text { gram }
\end{array}
$$

Tabel .9 Gradasi agregat.

\begin{tabular}{lcccccccc}
\hline $\begin{array}{l}\text { Ukuran } \\
\text { saringan }\end{array}$ & \multicolumn{3}{c}{ \% lolos agregat } & \multicolumn{3}{c}{ Proporsi agregat } & \multicolumn{2}{c}{ Spesifikasi } \\
\cline { 2 - 8 } & Kasar & sedang & Halus & $\begin{array}{l}\text { Kasar } \\
\mathbf{2 3 \%}\end{array}$ & Sedang3\% & $\begin{array}{l}\text { Halus } \\
\mathbf{3 9 \%}\end{array}$ & Total & Bina marga \\
\hline 1 1/2 & 100 & 100 & 100 & 23 & 36 & 39 & 100 & 100 \\
\hline 1 & 100 & 100 & 100 & 23 & 36 & 39 & 100 & 100 \\
\hline $3 / 4$ & 100 & 100 & 100 & 23 & 36 & 39 & 100 & 100 \\
\hline $1 / 2$ & 73,55 & 100 & 100 & 16,92 & 36 & 39 & 93,92 & $90-100$ \\
\hline $3 / 8$ & 27,60 & 99,66 & 100 & 6,35 & 35,88 & 39 & 83,22 & $77-90$ \\
\hline No.4 & 2,84 & 36,47 & 99,65 & 0,65 & 13,13 & 38,87 & 54,65 & $53-69$ \\
\hline No.8 & 0,83 & 5,32 & 83,71 & 0,19 & 1,91 & 32,65 & 36,75 & $33-53$ \\
\hline No 16 & 0,57 & 3,21 & 55,14 & 0,13 & 1,16 & 21,51 & 24,79 & $21-40$ \\
\hline
\end{tabular}




\begin{tabular}{lcccccccc}
\hline $\begin{array}{l}\text { Ukuran } \\
\text { saringan }\end{array}$ & \multicolumn{3}{c}{ \% lolos agregat } & \multicolumn{3}{c}{ Proporsi agregat } & & Spesifikasi \\
\cline { 2 - 9 } & Kasar & sedang & Halus & $\begin{array}{l}\text { Kasar } \\
\mathbf{2 3 \%}\end{array}$ & Sedang36\% & $\begin{array}{l}\text { Halus } \\
\mathbf{3 9 \%}\end{array}$ & Total & Bina marga \\
\hline No 30 & 0,48 & 2,31 & 40,26 & 0,11 & 0,83 & 15,70 & 18,64 & $14-30$ \\
\hline N0 50 & 0,00 & 0,95 & 30,56 & 0,00 & 0,34 & 11,92 & 14,26 & $9-22$ \\
\hline No 100 & 0,00 & 0,60 & 19,17 & 0,00 & 0,21 & 7,48 & 9,69 & $6-15$ \\
\hline No 200 & 0,00 & 0,44 & 9,48 & 0,00 & 0,16 & 3,70 & 5,86 & $4-19$ \\
\hline
\end{tabular}

Hasil Marshall Tes

Tabel 10 Hasil Pengujian Marshall

Kadar aspal $\quad: 5,5 \%$

Jumlah tumbukan:75 X 2

Angka kalibrasi : 13,9455

\begin{tabular}{|c|c|c|c|c|c|c|c|c|}
\hline Filler & $\begin{array}{l}\text { Berat } \\
\text { kering }\end{array}$ & $\begin{array}{c}\text { Berat } \\
\text { dalam air }\end{array}$ & SSD & $\begin{array}{c}\begin{array}{c}\text { Densitas } \\
\text { gr/cc }\end{array} \\
\end{array}$ & $\begin{array}{c}\text { Pembacaan } \\
\text { dial }\end{array}$ & $\begin{array}{c}\begin{array}{c}\text { Stabilitas } \\
(\mathrm{kg})\end{array} \\
\end{array}$ & $\begin{array}{l}\text { Flow } \\
(\mathbf{m m})\end{array}$ & $\begin{array}{c}M Q \\
(\mathrm{~kg} / \mathrm{mm}) \\
\end{array}$ \\
\hline semen & 1181,5 & 685,2 & 1196,4 & 2,35 & 81,7 & 1059,58 & 4.21 & 252 \\
\hline semen & 1180 & 678,4 & 1184,5 & 2,12 & 77,1 & 1107,44 & 4,33 & 256 \\
\hline semen & 1189 & 690,5 & 1189,2 & 2,34 & 82,6 & 1048,13 & 3,90 & 269 \\
\hline Rata-rata & 1183,5 & 684,7 & 1190 & 2,27 & 80,4 & 1071,71 & 4,14 & 259 \\
\hline $100 \%$ fly ash & 1189,2 & 691,5 & 1190,7 & 2,38 & 62,6 & 811,87 & 2,90 & 279 \\
\hline $100 \%$ fly ash & 1190 & 678,8 & 1192.5 & 2,31 & 61,2 & 879,06 & 3,30 & 266 \\
\hline $100 \%$ fly ash & 1181 & 678,7 & 1183,3 & 2,29 & 62,1 & 892,15 & 3,10 & 288 \\
\hline Rata-rata & 1186.7 & 683,2 & 1188.3 & 2,32 & 61,9 & 861,20 & 3,10 & 276 \\
\hline $100 \%$ batu bata & 1194,5 & 685,2 & 1196,4 & 2,33 & 67,6 & 971,3 & 4,35 & 223 \\
\hline $100 \%$ batu bata & 1180,2 & 678,4 & 1184,5 & 2,33 & 69,4 & 900,16 & 4,40 & 205 \\
\hline $100 \%$ batu bata & 1186,7 & 690,5 & 1189,2 & 2,38 & 70,3 & 911,73 & 4,33 & 211 \\
\hline Rata-rata & 1187,2 & 684,7 & 1190 & 2,34 & 69,1 & 927,64 & 4,36 & 213 \\
\hline $\begin{array}{c}50 \% \text { bb:50\% fly } \\
\text { ash }\end{array}$ & 1182,2 & 672,4 & 1192,4 & 2,28 & 68,1 & 883,20 & 3,30 & 267 \\
\hline $\begin{array}{c}50 \% \text { bb:50\% fly } \\
\text { ash }\end{array}$ & 1183,4 & 682,3 & 1184,3 & 2,34 & 72,6 & 921,32 & 3.60 & 256 \\
\hline $\begin{array}{c}50 \% \text { bb:50\% fly } \\
\text { ash }\end{array}$ & 1189,8 & 674,2 & 1193,7 & 2,29 & 63,5 & 962,37 & 3,15 & 306 \\
\hline Rata-rata & 1185,1 & 675,6 & 1190 & 2,30 & 68,0 & 922,29 & 3,35 & 276 \\
\hline
\end{tabular}

Sumber : Hasil penelitian

Hasil uji marshall pada aspal dengan filler $100 \%$ semen Portland sebgai acuan dengan membadingkan pengantian filler dengan fly ash batu bara dan serbuk batu bata metode pengujian menggunakan (RSNI M-01-2003) dengan kepadatan mutlak yaitu dengan $75 \mathrm{x}$ tumbukan atas dan bawah.hasil pengujian dapat dilihat pada tabel 10. Marshall tes dilakukan di laboratorium UNISLA marshall tes untuk menghitung nilai stabilitas, flow densitas dan marshall questient.

\section{Stabilitas(kg)}

Stabilitas dibutuhkan untuk mengetahui seberapa besar faktor kemampuan perkerasan untuk menahan beban lalu lintas tanpa menimbulkan perubahan yang tetap,seperti gelombang,alur,blending, yang bergradasi rapat memberikan rongga antar butiran yang kecil yang dapat menghasilkan nilai stabilitas yang tinggi .pada penilitian ini menggunakan filler normal yaitu semen portlan $100 \%$. Dapat dilihat pada gambar 2 nilai pengujian stabilitas.

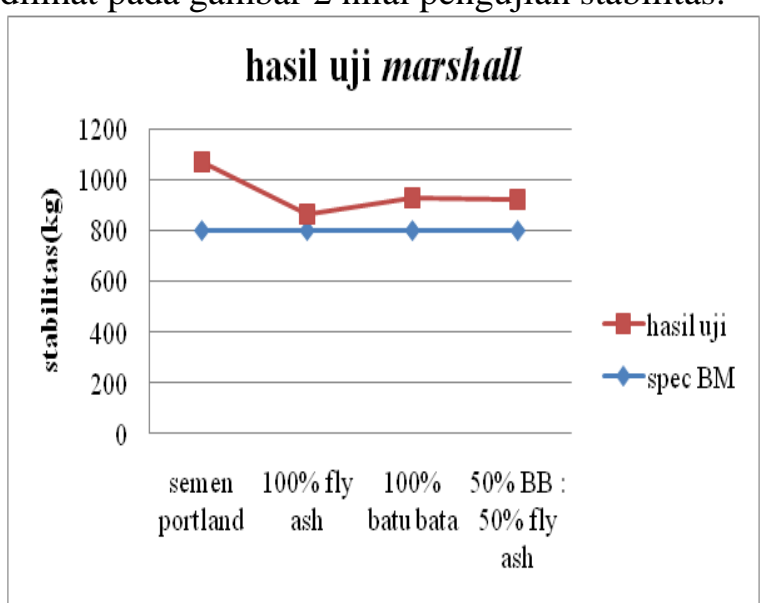

Gambar 2 Nilai Stabilitas 
Dari hasil penelitian gambar 2 diatas dapat di ketahui bahwa nilai stabilitas memenuhi standar spesifikasi yang di keluarkan bina marga yaitu sebesar 800 kg.nilai stabilitas tertinggi yaitu menggunakan filler semen $100 \%$.dan nilai terendah pada filler dengan $100 \%$ fly ash karna mengalami blending.

\section{$\operatorname{Densitas(gr/cc)}$}

Densitas diperlukan pada lapisan permukaan sehingga lapisan ini dapat menahan keausan akibat cuaca,air dan perubahan suhu ataupun gesekan kendaraan dan untuk mengetahui nilai penyerapan aspal.semakin besar nilai aspal akan menghasilkan densitas yang bagus pengujian dapat dilihat pada gambar 3

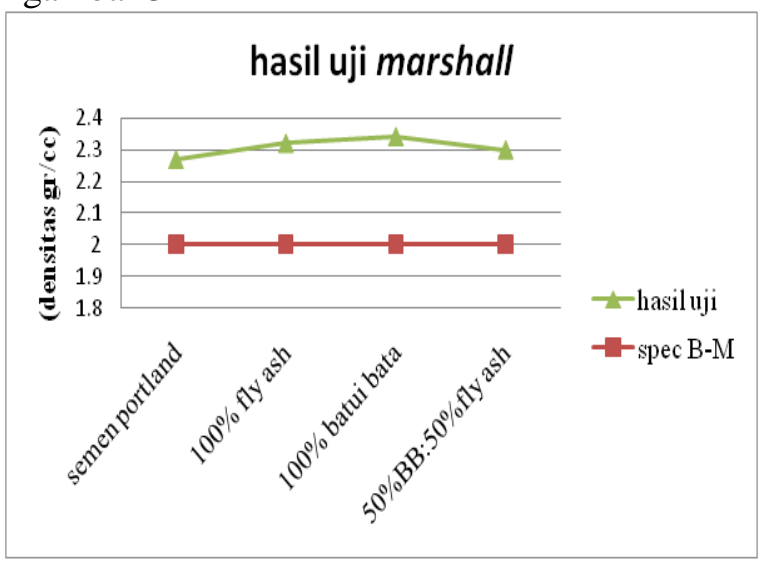

Gambar 3 Nilai Densitas

Dari hasil pengujian pada gambar 3 diatas bahwa nilai peneyerapan aspal sudah memenuhi spesifikasi bina marga yaitu diatas 2,00 dapat dilihat tidak terlalu signifikan penyerapan yang terjadi diantara semua filler yang di ujikan.

\section{Flow/kelelehan(mm)}

Flow/kelelehan menunjukkan nilai penurunan atau deformasi yang terjadi pada lapis keras akibat menahan beban yang diterimanya penurunan atau deformasi yang terjadi erat kaitannya dengan nilai karakteristik campuran marshall lainnya. Flow juga dipengaruhi oleh gradasi agregat dan terhadap kadar aspal, semakin besar kadar aspal semakin besar pula kelelehannya. Pada pengujian ini memakai kadar aspal sebesar $5,5 \%$. Hasil pengujian dapat dilihat pada gambar 4.

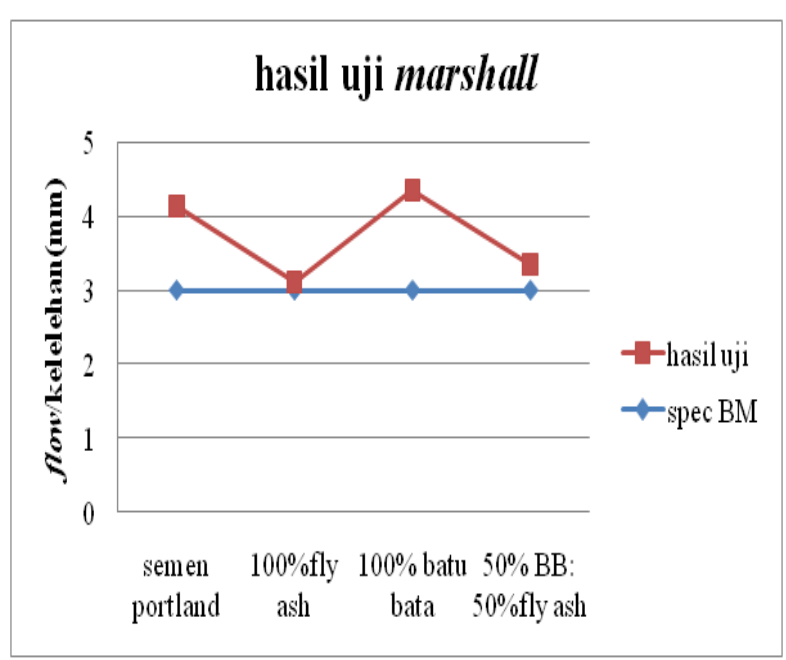

Gambar 4 Nilai Flow

Dari hasil pengujian pada gambar 4 nilai flow/kelelehan sudah memenuhi spesifikasi yang di standartkan oleh bina marga yaitu nilai minimum 3,00 .nilai kelelehan terbesar terjadi pada filler dengan 100\% serbuk batu bata untuk filler fly ash masih memenuhi standart meskipun nilainya rendah di bandingkan dengan filler semen portland.

\section{Marshall Questient MQ (kg/mm)}

Marshall questient $(M Q)$ merupakan hasil bagi antara stabilitas dan flow/kelelehan dan merupakan pendekatan terhadap tingkat kekakuan dan fleksibilitas campuran, semakin besar nilai marshall questient (MQ) maka semakin kaku dan sebaliknya semakin kecil nilai marshall questient( $M Q$ ) maka semakin lentur. Pada pengujian ini melakukkan pengantian filler yaitu semen portland sebagai pembanding pada filler fly ash dan serbuk batu bata. Nilai marshall questient $(M Q)$ dapat dilihat pada gambar 5 .

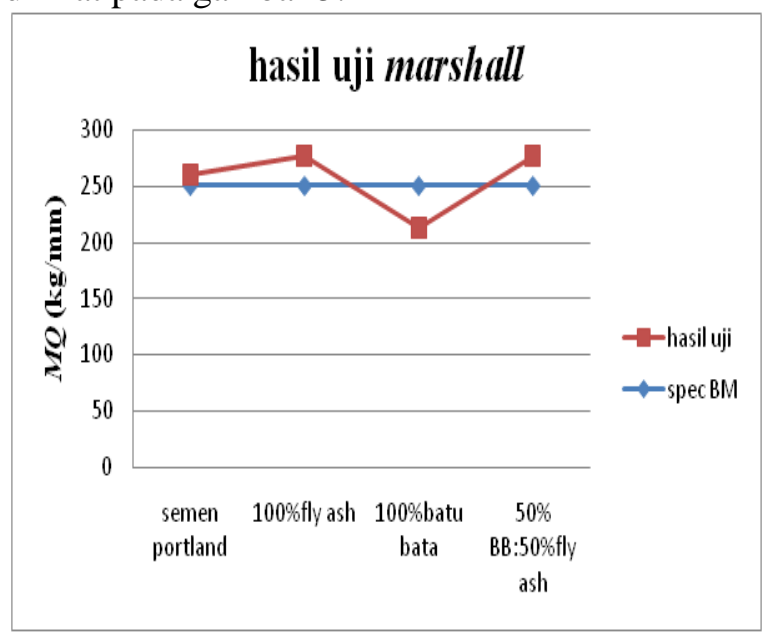

Gambar 5 Nilai Marshall Questient 
Dari hasil penelitian pada gambar 5 diatas nilai marshall questient $(M Q)$ tertinggi terjadi pada filler dengan $100 \%$ fly ash dan perbandingan antara serbuk batu bata dengan fly ash yaitu sama $276 \mathrm{~kg} / \mathrm{mm}$, nilai marshall questient $M Q$ yang tidak memenuhi spesifikasi bina marga adalah filler dengan $100 \%$ serbuk batu bata merah.

\section{PENUTUP}

\section{Kesimpulan}

a) Pada pengujian stabilitas benda uji dengan $100 \%$ fly ash mengalami blending. Meskipun nilai stabilitasnya rendah tapi masih memenuhi spesifikasi bina marga. Sifat fly ash yang licin membuat bahan filler tersebut mengalami blending/ keruntuhan.

b) Nilai marshall questient $M Q$ pada benda uji $100 \%$ serbuk batu bata merah tidak memenuhi spesifikasi bina marga yaitu kurang dari $250 \mathrm{~kg} / \mathrm{mm}$.

c) Pengujian terbaik yaitu dengan filler semen Portland dikarnakan sifat pozollan dan zat yang terkandung dalam semen sangat baik digunakan sebagai bahan pengisi atau filler pada aspal. Dari pengujian stabilitas, flow densitas maupun $M Q$ hasil dari pada semen sangat bagus.

d) Nilai hasil uji marshall perbandingan antara 50\% batu bata dengan 50\% fly ash menghasilkan hasil yang bagus, baik nilai stabilitas flow maupun hasil bagi marshall atau marshall questient.

\section{DAFTAR PUSTAKA}

Adibroto F. Yelfi 2008 ,Pemanfaatan Limbah Abu Batu Bara Sebagai Bahan Penganti Semen Dan Agregat Untuk Pembuatan Blockhttp://ojs.polinpdg.ac.id

Ali H.,2011Karakteristik Campuran Asphalt Concrete-Wearing Course(ACWC)Dengan Penggunaan Abu Vulkanik Dan Abu Batu Bara Sebagai Filler,Jurnal Fakultas Teknik Universitas Lampung.Lampung

Ambarwati dan Arifin (2009), Karakteristik Batu Bata,Jurnal Sipil vol 4edisis desember (2009).Universitas
ASTM C150 2007 Standart Specification For PortlandCementCement.copyright@int ernational united state

$\begin{array}{llll}\text { AASHTO } & 1990 \quad .15 & \text { Edtion.Standart }\end{array}$ Specification For Transportation Material And Methods Of Sampling And Testing.Part II ,Washington.USA

Anonim,2010 ,Spesifikasi Umum. Direktorat bina marga .Jakarta.

Anonim,1987Spesifikasi Umum.Dinas Pekerjaan Umum direktorat jenderal bina marga.jakarta

Anonim2015 Panduan Praktikum Perkerasan Jalan Raya.Teknik Sipil.Universitas Islam Lamongan

Fauzi (2012) Usaha Pembuatan Batu Bata merah,http://usaha jepara.blogspot.com/2012

Bengkulu,Bengkulu 
Halaman ini sengaja dikosongkan 